\title{
The Effect of Fibrolytic Enzymes Sprayed onto Forages and Fed in a Total Mixed Ratio to Lactating Dairy Cows ${ }^{1}$
}

\author{
L. Kung, Jr.*, M. A. Cohen*, L. M. Rode†,2, and R. J. Treacherł \\ *Delaware Agricultural Experiment Station \\ Department of Animal and Food Sciences \\ College of Agriculture \& Natural Resources \\ University of Delaware \\ Newark 19717-1303 \\ †Agriculture and Agri-Foods Canada \\ Lethbridge, Canada \\ fFinnfeeds International Ltd. \\ Marlborough, Wiltshire, U.K.
}

\begin{abstract}
We investigated the effect of spraying different combinations of fibrolytic enzymes onto forages on their nutritive value for lactating cows. Holstein cows were fed a TMR consisting of $30 \%$ corn silage, $15 \%$ alfalfa hay, and 55\% concentrate (dry matter basis). During a 12 -wk treatment period, the forages were treated with no enzymes (control), cellulase D and sultanas B, or cellulase D and xylanase C. Enzymes were diluted in water and sprayed onto the forages while mixing. Both combinations of enzymes supplied similar amounts of fibrolytic activity based on classical enzyme assays conducted at $50^{\circ} \mathrm{C}$. Cows fed forages treated with cellulase $\mathrm{D}$ and xylanase $\mathrm{B}$ tended to produce more $3.5 \%$ FCM $(+2.5 \mathrm{~kg} / \mathrm{d})$ than did cows fed the untreated forages. Dry matter intake, milk production, milk fat, and milk protein were unaffected by treatment. In vitro production of gas from forages treated with enzymes was greater than from untreated forage, but 96-h volatile fatty acid production was not different among treatments. With an alternative enzyme assay based on the depolymerization of dyed substrate at $40^{\circ} \mathrm{C}$, activity of xylanase $\mathrm{C}$ was greatest at a $\mathrm{pH}$ of 6.5 but was substantially reduced as the $\mathrm{pH}$ of the assay was decreased. In contrast, xylanase B showed highest activity at $\mathrm{pH} 5$ and enzyme activity was twice that of xylanase B at pH 5.5 and 6. Overall, the results of this study provide more evidence that fibrolytic enzymes can be used to improve milk production in lactating cows.
\end{abstract}

(Key words: cellulase, xylanase, enzyme, dairy cow)

\footnotetext{
Received July 30, 2001.

Accepted October 18, 2001.

Corresponding author: L. Kung, Jr.; e-mail: lkung@udel.edu.

${ }^{1}$ Published as a miscellaneous paper of the Delaware Agricultural Experiment Station.
}

\section{INTRODUCTION}

Feeding ruminants exogenous enzymes was previously an unacceptable practice because these proteins were thought to be degraded by ruminal proteases (Kopecny et al., 1987). However, Fontes et al. (1995) reported that some xylanases were extremely stable in ruminal fluid. Additionally, Hristov et al. (1998) reported that when added directly to the rumen, fibrolytic enzymes maintained partial activity, which refuted the earlier theory.

Fibrolytic enzymes may also be partially protected from ruminal degradation when they are sprayed onto feeds because binding with substrates may cause conformational changes that may protect these exogenous enzymes from ruminal proteases (Fontes et al., 1995). Treating feeds with fibrolytic enzymes just before feeding has improved animal performance (Schingoethe et al., 1999; Beauchemin et al., 2000). For example, Stokes and Zheng (1995) reported that spraying enzymes on forage increased DMI by $10.7 \%$ and milk yield by $14.7 \%$. Rode et al. (1999) reported that treatment of a barley-based concentrate with fibrolytic enzymes resulted in marked improvements in $\mathrm{OM}$ and fiber digestion of a TMR fed to lactating cows. Cows fed the diet supplemented with enzymes produced $10 \%$ more milk than cows fed the untreated TMR. Our laboratory (Kung et al., 2000) has also obtained positive production responses from lactating cows fed a TMR whose forage had been treated with cellulase and xylanase enzymes. Morgavi et al. (2000) suggested that synergy between ruminal fibrolytic enzymes (associated with highest cellulolytic activity at rumen $\mathrm{pH}$ above 6.2) and exogenous fibrolytic enzymes (with $\mathrm{pH}$ optimums below 6.0) may be responsible for improvements in animal production when ruminants are fed feeds treated with enzymes.

The objective of this study was to evaluate the effect of treating forages with various cellulase and xylanase 
Table 1. Ingredient composition of the concentrate.

\begin{tabular}{ll}
\hline Ingredient & $\%$, DM basis \\
\hline Wheat midds & 30 \\
Brewers grain & 15 \\
Soybean meal, 47.5\% CP & 14.9 \\
Corn gluten feed & 7.5 \\
Molasses supplement & 7 \\
Canola meal & 6.5 \\
Distillers dried grains & 6.3 \\
Corn meal & 5 \\
Fat-blend & 1.65 \\
Salt & 1.5 \\
SQ-810 & \\
1.5 & \\
Calcium phosphate & \\
Limestone & 1.2 \\
Magnesium oxide & 1.1 \\
Selenium & \\
Trace minerals & \\
Vitamins $^{5}$ & 0.6 \\
\hline
\end{tabular}

\footnotetext{
${ }^{1}$ Contained $90 \%$ fatty acids.

${ }^{2}$ Sodium sesquicarbonate ( $43.4 \%$ sodium carbonate and $34.4 \%$ sodium bicarbonate).

${ }^{3}$ Contained (DM basis) $612 \mathrm{mg} / \mathrm{kg}$ selenium.

${ }^{4}$ Contained (DM basis) $14.4 \% \mathrm{~S}, 7.5 \% \mathrm{Ca}, 1102 \mathrm{mg} / \mathrm{kg}$ of cobalt, $27,244 \mathrm{mg} / \mathrm{kg}$ of $\mathrm{Cu}, 4112 \mathrm{mg} / \mathrm{kg}$ of I, $9520 \mathrm{mg} / \mathrm{kg}$ of Fe, 108,877 mg/ $\mathrm{kg}$ of $\mathrm{Mn}$, and $108,877 \mathrm{mg} / \mathrm{kg}$ of $\mathrm{Zn}$.

${ }^{5}$ Contained (DM basis) 28,696 KIU/kg of vitamin A, $7173 \mathrm{KIU} / \mathrm{kg}$ of vitamin D, and 179,346 IU/kg of vitamin $\mathrm{E}$.
}

combinations and the subsequent effect on milk production and composition when fed to lactating dairy cows.

\section{MATERIALS AND METHODS}

Twenty-seven multiparous and three primiparous Holstein cows averaging $93 \pm 47$ DIM and average milk production of about $40 \mathrm{~kg} / \mathrm{d}$ were offered a complete diet as a TMR once daily for a 14-d pretreatment period. The first $4 \mathrm{~d}$ were used to accustom cows to feeding (once daily at $1400 \mathrm{~h}$ ) via Calan gates (American Calan, Northwood, $\mathrm{NH}$ ), and the data from the next $10 \mathrm{~d}$ were used for covariant adjustment. The TMR was $30 \%$ (DM basis) corn silage mixed with $15 \%$ chopped alfalfa hay and $55 \%$ of a pelleted concentrate (Table 1). Cows were fed ad libitum and feed refusals were measured daily. Fresh water was available at all times, and the care of animals was via accepted protocols (Anon. 1989). After the pretreatment period, cows were blocked on parity and milk yield and randomly allocated to one of three treatments. During a 12 -wk treatment period the forage portion of the TMR was treated with: 1) no enzymes, 2) cellulase complex D and xylanase complex B (3400 carboxymethyl cellulase units and 10,450 xylanase units/kg of forage DM), or 3) cellulase complex D and xylanase complex C (3350 carboxymethyl cellulase units and 10,500 xyla- nase units/kg of forage DM). Enzymes were mixed, diluted with water, and sprayed (within $30 \mathrm{~min}$ of mixing) onto the corn silage and hay (10 L/tonne of fresh forage) while mixing. A similar amount of water was added to untreated forage in treatment 1 . The pelleted concentrate was mixed with the forages to form a TMR that was fed to animals within 30 min of enzyme treatment.

Milk production was recorded by a computer twice daily at 0500 and $1500 \mathrm{~h}$. Once weekly, milk was sampled proportionately to milk yield from consecutive p.m. and a.m. milkings and analyzed for fat and protein (Milk-O-Scan, Foss Technology, Hillerød, Denmark). Body weights were recorded at the start and end of the study and twice weekly throughout the study. Ambient temperatures were recorded daily.

Samples of corn silage, alfalfa hay, concentrates, and TMR were collected three times weekly and composited on a weekly basis. The mixture of corn silage and alfalfa hay (after treatment with water or enzymes) was also collected three times weekly and composited on a weekly basis. Once weekly, a representative sample of each TMR was subjected to quantitative measurements of particle size using a Pennsylvania State particle size separator (Pennsylvania State University, University Park, PA). The distribution of feed particle size was done on each TMR in duplicate. Dry matter of the samples was determined in a forceddraft oven at $60^{\circ} \mathrm{C}$ for $48 \mathrm{~h}$. After drying, feed samples were ground through a Wiley Mill (1-m screen, Arthur H. Thomas, Philadelphia, PA) and analyzed for lab $\mathrm{DM}\left(100^{\circ} \mathrm{C}\right.$ oven for $\left.24 \mathrm{~h}\right), \mathrm{NDF}$ using sulfite and amylase (Van Soest et al., 1991) and ADF (Robertson and Van Soest, 1981). Crude protein was calculated by multiplying total $\mathrm{N}$ by 6.25 after total combustion (Leco CNS 528 Analyzer, St. Joseph, MI). Starch was analyzed using the method described by Poore et al. (1993). Dietary ingredients and enzyme applications were adjusted weekly based on the DM content of the feeds. Ten grams of the weekly corn silage samples was homogenized with $100 \mathrm{ml}$ of deionized water for $1 \mathrm{~min}$, and the $\mathrm{pH}$ of the mixture was immediately recorded.

Portions of the forage mixes (corn silage and alfalfa hay) from the three treatments were composited on a biweekly basis and freeze dried before grinding through a $1-\mathrm{mm}$ screen. Rate of in vitro fermentation rate was determined. Gas production was measured over $48 \mathrm{~h}$ using the automated system developed by Isaasa et al. (1998). Approximately $500 \mathrm{mg}$ of each sample was placed into serum vials and mixed with strained ruminal fluid and a bicarbonate/phosphate buffer. Anaerobic techniques were employed in all transfers of medium. Vials were purged with $\mathrm{CO}_{2}$ and 
Table 2. Least squares means of the chemical composition of the individual feeds fed during the lactation study.

\begin{tabular}{llll}
\hline Item & Corn silage & Alfalfa hay & Concentrate \\
\hline $\mathrm{DM}, \%$ & $36.6 \pm .01$ & $91.7 \pm 1.8$ & $93.4 \pm 1.6$ \\
$\mathrm{pH}$ & $3.45 \pm 0.07$ & $\mathrm{ND}^{1}$ & $\mathrm{ND}$ \\
$\mathrm{CP}, \%$ & $7.7 \pm 1.2$ & $17.3 \pm 2.5$ & $26.3 \pm 0.7$ \\
$\mathrm{Starch}, \%$ & $33.5 \pm 4.9$ & $1.2 \pm 0.4$ & $17.6 \pm 2.3$ \\
$\mathrm{NE}_{\mathrm{L}}, \mathrm{Mcal} / \mathrm{kg}^{2}$ & $1.63 \pm 0.04$ & $1.06 \pm 0.13$ & $1.69 \pm 0.02$ \\
$\mathrm{ADF}, \%$ & $25.0 \pm 2.7$ & $44.7 \pm 4.5$ & $14.4 \pm 1.2$ \\
$\mathrm{NDF}, \%$ & $43.0 \pm 4.5$ & $57.3 \pm 4.7$ & $30.7 \pm 3.0$ \\
\hline
\end{tabular}

${ }^{1}$ Not determined.

${ }^{2}$ Net energy of lactation.

crimp-sealed before incubating at $39^{\circ} \mathrm{C}$. Vials were allowed to equilibrate for $5 \mathrm{~min}$, and, as fermentation proceeded, the gas produced was recorded every $30 \mathrm{~s}$ by a pressure and voltage reading. After $48 \mathrm{~h}$, VFA were measured by gas liquid chromatography (HP 5890, Hewlett Packard, Palo Alto, CA) on a capillary column (Supelco Nukol, $30 \mathrm{~m} \times 0.32 \mathrm{~mm}$ diameter and $1-\mu \mathrm{m}$ phase thickness (Sigma-Aldrich Canada Ltd., Oakville, ON) with flame-ionization detection. Crotonic acid was used as an internal standard. Parameters for rte and extent of gas production were determined by fitting hourly gas production data to the equation used by ørskov and McDonald (1979).

For standardizing and quantifying enzyme activity, cellulase enzyme complex D was incubated with carboxymethyl cellulose at $50^{\circ} \mathrm{C}$ for $10 \mathrm{~min}$ at a $\mathrm{pH}$ of 4.8 and reducing sugars released per min as glucose equivalents using the dinitrosalicylic acid procedure was determined (Nelson, 1944). Xylanase activity was determined by incubating the enzyme complexes (B and $\mathrm{C}$ ) with oat spelts xylan at $50^{\circ} \mathrm{C}$ for $30 \mathrm{~min}$ at a $\mathrm{pH}$ of 5.3 and determining the reducing sugars released per minute (Nelson, 1944) as xylose equivalents. The assays were conducted by Finnfeeds International (Marlborough, England).

In addition to using the assay procedures just mentioned, the effect of $\mathrm{pH}$ on enzyme activities was determined via an alternative method (Megazyme International Ireland Ltd., Co. Wicklow, Ireland). Specifically, the cellulase enzyme D was assayed for endo- $1,4-\beta-\mathrm{D}$ glucanase activity and xylanase $B$ and $C$ enzymes were assayed for endo-1,4- $\beta$-D xylanase activity. Substrates (carboxymethyl cellulose for cellulase and azo-xylan for xylanase) were dyed with remazolbrilliant blue R. Upon incubation with the enzymes, the substrates were partially depolymerized and low molecular weight dyed fragments were released into solution and measured at $590 \mathrm{~nm}$. The $\mathrm{pH}$ of the assays varied from 3.0 to 7.0 with a citrate phosphate buffer. AT each level of $\mathrm{pH}$, preequilibrated enzyme solution or buffer alone was added to preequilibrated substrate solution in duplicate, and the mixture stirred on a vortex mixer. For both enzyme assays, solutions were incubated at $60^{\circ} \mathrm{C}$ for $10 \mathrm{~min}$. For the cellulase assay, the reactions were ended by the addition of $0.5 \mathrm{ml}$ of a precipitant solution (76\% ethanol, $4 \%$ sodium acetate trihydrate, $0.4 \%$ zinc acetate, and $19.6 \%$ deionized water). For the xylanase assays the reactions were terminated using 95\% ethanol. The solutions were then centrifuged at $1000 \times g$ for $10 \mathrm{~min}$ and the absorbency of the supernatants determined at $590 \mathrm{~nm}$. Units were expressed as $\mathrm{OD}$ at 590 (minus blanks and controls).

\section{Statistical Analyses}

Lactation data and feed composition data were analyzed using the general linear models procedure of SAS (1998) as a completely randomized design. Data from the 10-d pretreatment period were used as covariates for all variables in the lactation trial. Significance was declared at $P<0.05$, and a tendency for significance was set at $P<0.12$. For the gas production data, nonlinear parameters a, b, and c were estimated by iterative least squares procedure (SAS, 1998) and best-fit values were chosen using the sum of squares after convergence. Statistical analysis was conducted using a oneway ANOVA. Mean separations were evaluated using LSD.

\section{RESULTS AND DISCUSSION}

The ambient temperature at feeding ranged from 2 to $20^{\circ} \mathrm{C}$ throughout the 12 -wk treatment period. The

Table 3. Least squares means of the composition of forage mix (corn silage and alfalfa hay) after treatment with enzymes $(\mathrm{D}=$ a cellulae enzyme complex; $\mathrm{B}=$ a xylanase enzyme complex; $\mathrm{C}=\mathrm{a}$ xylanase enzyme complex).

\begin{tabular}{lllll}
\hline Item & Control & Enzymes D + B & Enzymes D + C & $\mathrm{SE}^{1}$ \\
\hline $\mathrm{DM}, \%$ & 41.9 & 42.4 & 42.1 & 2.1 \\
CP, \% & 11.69 & 11.94 & 11.95 & 0.48 \\
Starch, \% & 22.3 & 22.0 & 21.6 & 1.1 \\
ADF, \% & 30.0 & 30.6 & 30.7 & 0.7 \\
NDF, \% & 47.2 & 47.2 & 47.0 & 0.9 \\
\hline${ }^{1} \mathrm{n}=12$. & & &
\end{tabular}


Table 4. Least squares means of the chemical composition and distribution of particle size in a TMR whose forage portion was treated with enzymes $(\mathrm{D}=$ a cellulase enzyme complex; $\mathrm{B}=\mathrm{a}$ xylanase enzyme complex; $\mathrm{C}=\mathrm{a}$ xylanase enzyme complex).

\begin{tabular}{lcccc}
\hline Item & Control & Enzymes D + B & Enzymes D + C & SE $^{1}$ \\
\hline DM, \% & 57.9 & 57.8 & 57.7 & 1.0 \\
CP, \% of DM & 18.34 & 18.33 & 18.27 & 0.27 \\
NE , Mcal/kg & 1.56 & 1.56 & 1.56 & $<0.01$ \\
ADF, \% & 22.2 & 22.3 & 22.2 & 0.5 \\
NDF, \% & 39.0 & 38.3 & 38.5 & 0.7 \\
Minerals (DM basis) & & & & 0.85 \\
Ca, \% & 0.86 & 0.88 & 0.75 & 0.03 \\
P, & 0.76 & 0.77 & 0.50 & 0.02 \\
Mg, \% & 0.53 & 0.51 & 1.42 & 0.11 \\
K, \% & 1.71 & 1.69 & 0.49 & 0.08 \\
Na, \% & 0.59 & 0.54 & 271 & 9 \\
Fe, ppm & 296 & 292 & 109 & 9 \\
Mn, ppm & 115 & 113 & 119 & 2 \\
Zn, ppm & 105 & 119 & 23 & 1.1 \\
Cu, ppm & 25 & 21 & 6.2 & 1.5 \\
Distribution of TMR particles, \% (fresh basis) & & & 34.0 & 1.4 \\
Top screen & 4.7 & 5.3 & 59.8 & \\
Middle screen & 33.0 & 33.5 & & \\
Bottom pan & 62.3 & 61.2 & & \\
\hline
\end{tabular}

${ }^{1} \mathrm{n}=12$.

chemical compositions of corn silage, alfalfa hay, and concentrate throughout the study are shown in Table 2 and for the corn silage and hay mixture (after treatment with enzymes) in Table 3 . All feeds were of good quality and normal nutrient composition. The chemical composition and particle size distribution of the TMR are shown in Table 4. The TMR averaged greater than $18 \% \mathrm{CP}$ and contained about $22.2 \% \mathrm{ADF}$ and $38.6 \% \mathrm{NDF}$. The distribution of particles among the three treatments were similar and within accepted guidelines (6 to $10 \%$ on top screen, 30 to $50 \%$ on the middle screen, and 40 to $60 \%$ on the bottom pan; Heinrichs et al., 1999). These results show that mixing times for the three TMR were similar and not biased for TMR that contained forages treated with enzymes.

The effect of enzymes on DMI, milk production, milk composition, and BW is shown in Table 5. The DMI ranged from 26.9 to $27.8 \mathrm{~kg} / \mathrm{d}$. Treatments had no effect on DMI, which is similar to results reported in some studies (Rode et al., Kung et al., 2000). However, enzymes have improved DMI in other studies (Stokes and Zheng, 1995; Lewis et al., 1999), and the reasons for these conflicting results are unknown. Milk fat and protein (percentage and yield) were not affected by enzyme treatment. However, the tendencies for lower milk fat percentage from cows fed enzyme-treated diets have been reported by Kung et al. (2000) and Rode et al. (1999). Milk production was not affected by treatment, but cows fed forage treated with the enzyme mixture of cellulase $\mathrm{D}$ and xylanase $\mathrm{B}$ produced $2.5 \mathrm{~kg}$ more $3.5 \% \mathrm{FCM}(P<0.12)$ than those fed untreated forage. This increase in production is similar to that reported from cows fed forage treated with the same enzyme combination in a previous study

Table 5. Least squares means of the effects of treating forages with enzymes $(\mathrm{D}=\mathrm{a}$ cellulase enzyme complex; $\mathrm{B}=$ a xylanase enzyme complex; $\mathrm{C}=$ a xylanase enzyme complex) on milk production of lactating cows.

\begin{tabular}{lcccc}
\hline Item & Control & Enzymes D + B & Enzymes D + C & SE \\
\hline DIM & $95 \pm 39$ & $91 \pm 51$ & $91 \pm 55$ & \\
DMI, kg/d & 26.9 & 27.8 & 27.2 & 0.6 \\
Milk, kg/d & 37.2 & 39.0 & 36.8 & 1.2 \\
Milk fat, \% & 3.33 & 3.44 & 3.29 & 0.08 \\
Milk CP, \% & 3.10 & 3.14 & 3.09 & 0.05 \\
Milk CP, kg/d & 1.16 & 1.17 & 1.14 & 0.03 \\
3.5\% FCM* & 36.0 & 38.5 & 35.7 & 0.04 \\
FCM/DMI & 1.34 & 1.35 & 656 & 1.31 \\
BW, kg & 652 & 654 & -0.09 & 0.16 \\
ADG, kg/d & 0.05 & -0.03 & & \\
\hline
\end{tabular}

*DB $>$ C,$P<0.12$. DB $>$ DC, $P<0.08$. 


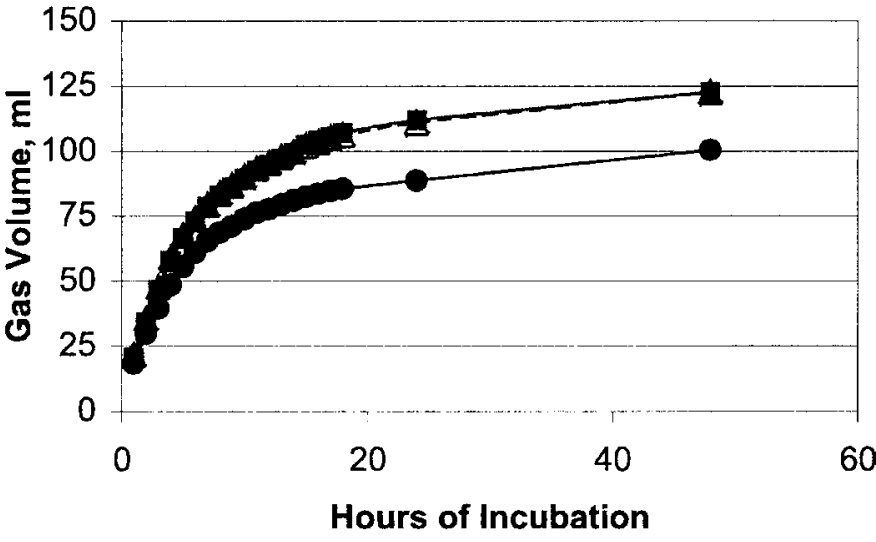

FIGURE 1. In vitro gas production of forages treated with enzymes $(\mathrm{D}=\mathrm{a}$ cellulase enzyme complex; $\mathrm{B}=\mathrm{a}$ xylanase enzyme complex; $\mathrm{C}$ = a xylanase enzyme complex)

(Kung et al., 2000). Feed efficiency, BW, and ADG over the 12 -wk treatment period was unaffected by treatment with enzymes.

Both enzyme combinations increased the extent of digestion $(P<0.05)$ as measured from gas production observations (Figure 1, Table 6). However, the rate of gas production was not affected by enzyme treatment. After $48 \mathrm{~h}$ of fermentation, concentrations of VFA were not affected by treatment (Table 7). Others have reported beneficial effects of treating feeds with enzymes on the in vitro production of gas. For example, Yang et al. (2000) reported that enzyme treatment reduced the lag time when enzymes were applied to the concentrate, but not to a TMR.

The amounts of cellulase (D) and xylanase enzymes (B and C) used to treat the forages were formulated based on classical enzyme assays where release of sugars was measured from a substrate of $\mathrm{pH}$ of 4.5 at $50^{\circ} \mathrm{C}$. However, these conditions do not accurately reflect the conditions in rumen of a lactating dairy cow. Thus an alternative method to determine relative enzyme activity was used. In that method, substrate was dyed

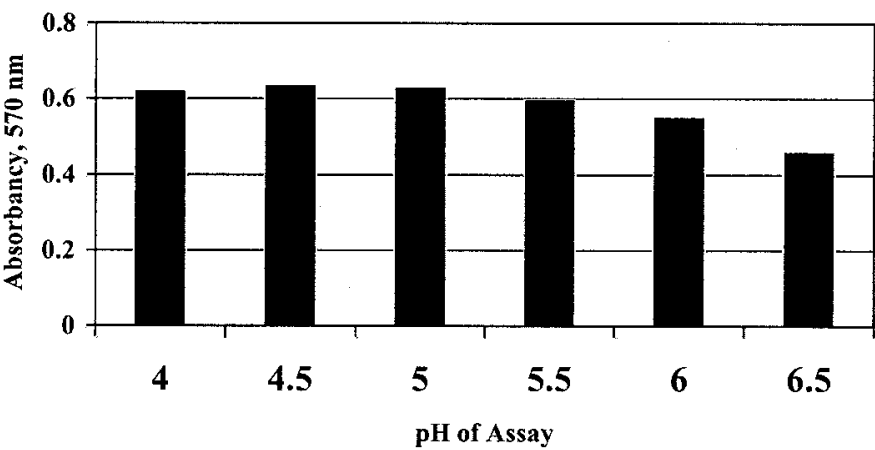

FIGURE 2. Enzyme activity of the cellulase enzyme D complex at different assay $\mathrm{pH}$.

with remazobrilliant blue $\mathrm{R}$ dye and when incubated at $40^{\circ} \mathrm{C}$ over a $\mathrm{pH}$ range of 4 to 7 , release of dyed from the substrate was quantified. The relative activity of cellulase D did not change appreciably (Figure 2) over a range of $\mathrm{pH}$ from 4 to 7 . However, enzyme activity was markedly different between xylanase $\mathrm{B}$ and $\mathrm{C}$ (Figure 3) depending on the $\mathrm{pH}$ of the assay. Activity of xylanase $\mathrm{C}$ was greatest at a $\mathrm{pH}$ of 6.5 but was substantially reduced as the $\mathrm{pH}$ of the assay was decreased. In contrast, xylanase B showed highest activity at $\mathrm{pH} 5$ and enzyme activity was twice that of xylanase $\mathrm{B}$ at $\mathrm{pH} 5.5$ and 6 . These findings may partially explain the discrepancy between enzyme effects on in vitro gas production and FCM production. The stimulation of in vitro gas production from forages treated with cellulase $\mathrm{D}+$ xylanase $\mathrm{B}$ and cellulase $\mathrm{D}$ + xylanase $\mathrm{C}$ was similar, probably because the $\mathrm{pH}$ of the rumen fluid and buffer mixtures was about 6.7 to 6.9 , resulting in high activity for both enzyme combinations. However, lactating cows fed high concentrate diets often have ruminal $\mathrm{pH}$ below 6.0 (Oba and Allen, 2000; Yang et al., 2000). Thus, the higher enzyme activity of xylanase $\mathrm{B}$ at $\mathrm{pH}$ lower than 6 , may have been the reason for the tendency for more FCM production from the combination of cellulase $\mathrm{D}+$ xylanase $\mathrm{B}$

Table 6. Parameters for in vitro gas production from forages treated with enzymes $(\mathrm{D}=\mathrm{a}$ cellulase enzyme complex; $\mathrm{B}=$ a xylanase enzyme complex; $\mathrm{C}=\mathrm{a}$ xylanase enzyme complex).

\begin{tabular}{lcccll}
\hline Parameter & Control & Enzymes D + B & Enzymes D + C & SE & $P$ value \\
\hline $\mathrm{a}^{1}$ & 3.24 & 3.97 & 5.07 & 0.68 & 0.62 \\
$\mathrm{~b}^{2}$ & $100.9^{\mathrm{a}}$ & $110.9^{\mathrm{b}}$ & $108.6^{\mathrm{b}}$ & 2.4 & 0.03 \\
$\mathrm{a}+\mathrm{b}$ & $102.4^{\mathrm{a}}$ & $114.8^{\mathrm{b}}$ & $113.6^{\mathrm{b}}$ & 3.4 & 0.09 \\
$\mathrm{c}^{3}$ & $0.164^{\mathrm{c}}$ & $0.154^{\mathrm{d}}$ & $0.159^{\mathrm{cd}}$ & 0.003 & 0.09 \\
\hline
\end{tabular}

\footnotetext{
${ }^{\mathrm{a}, \mathrm{b}}$ Means in the same row with different superscripts are different $(P<0.05)$.

${ }^{\mathrm{c}, \mathrm{d}}$ Means in the same row with different superscripts are different $(P<0.10)$.

${ }^{1}$ Initial gas production at time $=0, \mathrm{ml}$.

${ }^{2}$ Extent of gas production, $\mathrm{ml}$.

${ }^{3}$ Rate of gas production, ${ }^{-} \mathrm{h}$.
} 
Table 7. In vitro VFA concentrations $(\mathrm{mM})$ from forages treated with various enzyme mixtures $(\mathrm{D}=\mathrm{a}$ cellulase enzyme complex; $\mathrm{B}=\mathrm{a}$ xylanase enzyme complex; $\mathrm{C}=\mathrm{a}$ xylanse enzyme complex).

\begin{tabular}{lcccc}
\hline Item & Control & Enzymes D + B & Enzymes D + C & SE \\
\hline Acetic acid & 57.27 & 57.58 & 57.44 & 0.17 \\
Propionic acid & 21.73 & 21.65 & 21.88 & 0.13 \\
Isobutyric acid & 1.39 & 1.39 & 1.39 & 0.02 \\
Butyric acid & $12.92^{\mathrm{a}}$ & $12.87^{\mathrm{a}}$ & $12.71^{\mathrm{b}}$ & 0.06 \\
Isovaleric acid & 3.21 & 3.14 & 3.17 & 0.05 \\
Valeric acid & 2.69 & 2.51 & 2.56 & 0.08 \\
Total VFA & 112.64 & 112.88 & 112.71 & 1.29 \\
\hline
\end{tabular}

rather than the combination of cellulase D + xylanase C. Rumen cellulolytic bacteria are extremely sensitive to acidic conditions and a ruminal $\mathrm{pH}$ below 6.0 to 6.2 has generally been considered detrimental to growth of these bacteria (Russell and Wilson, 1996). Thus, the addition of fiber degrading enzymes that have high levels of activity when fibrolytic bacteria are compromised may be beneficial. Overall, these results support the theory of Morgavi et al. (2000), who suggested that synergy between ruminal and exogenous fibrolytic enzymes may explain how feed enzymes improve performance in ruminant animals.

\section{CONCLUSIONS}

Cows fed a TMR whose forage had been treated with cellulase and xylanase enzyme mixtures tended to produce more FCM than cows fed untreated forage but only when the xylanase used displayed a high level of enzyme activity over a wide range of $\mathrm{pH}$. These findings suggest that the effect of $\mathrm{pH}$ on enzyme activity over a wide range of $\mathrm{pH}$. These findings suggest that the effect of $\mathrm{pH}$ on enzyme activity may be an important factor in future studies when identifying fibrolytic enzymes for use in ruminant diets. Overall, the results of this study provide more evidence that fibrolytic enzymes can be used to improve milk production in lactating cows.

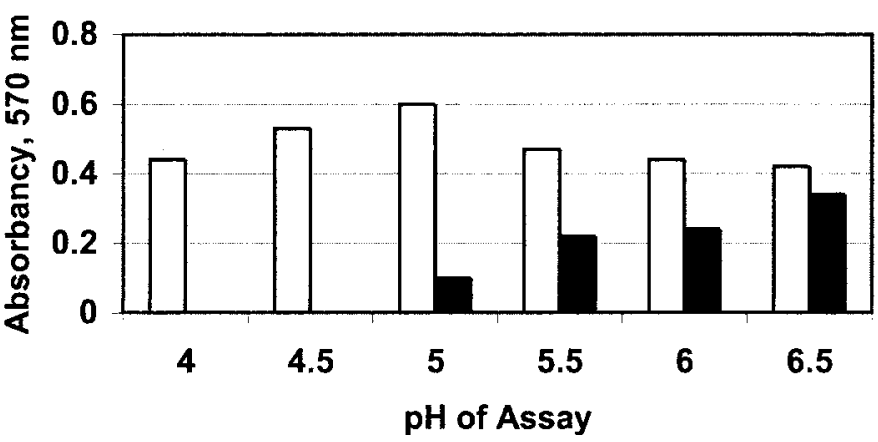

FIGURE 3. Enzyme activity of the xylanase B and C enzyme complexes at different assay $\mathrm{pH}$. Unshaded bars = xylanase B; Shaded bars $=$ xylanase $\mathrm{C}$.

\section{ACKNOWLEDGMENTS}

The authors thank Richard Morris for management of the cows. We thank John Pesek for help in statistical programming and Caroline Golt for assistance in VFA analysis.

\section{REFERENCES}

Anon. 1989. Handbook for Agricultural Animal Care and Use in Research and Teaching. Agricultural Animal Care and Use Committee, Univ. of Delaware, Coll. of Agric. Natural Res., Newark.

Beauchemin, K. A., L. M. Rode, M. Maekawa, D. P. Morgavi, and R. Kampen. 2000. Evaluation of a nonstarch polysaccharidase feed enzyme in dairy cow diets. J. Dairy Sci. 83:543-553.

Fontes, C. M., J. Hall, B. H. Hirst, G. P. Haslewood, and H. J. Gilbert. 1995. The resistance of cellulases and zylanases to proteolytic inactivation. Appl. Microbiol. Biotechnol. 43:52-57.

Heinrichs, A. J., D. R. Buckmaster, and B. P. Lammers. 1999. Processing, mixing, and particle size reduction of forages for dairy cattle. J. Anim. Sci. 77:180-186.

Hristov, A., T. A. McAllister, and K. J. Cheng. 1998. Effect of dietary or abomasal supplementation of exogenous polysaccharide-degrading enzymes on rumen fermentation and nutrient digestibility. J. Anim. Sci. 76:3146-3156.

Hristov, A. N., T. A. McAllister, and K.-J. Cheng. 2000. Intraruminal supplementation with increasing levels of exogenous polysaccharide-degrading enzymes: Effects on nutrient digestion in cattle fed a barley grain diet. J. Anim. Sci. 78:477-487.

Iwaasa, A. D., L. M. Rode, K. A. Beauchemin, and S. Eivemark. 1998. Cumulative gas production of alfalfa forage treated with different cell-wall degrading enzymes. J. Anim. Sci. (Suppl. 1):291 (Abstr.).

Kopecny, J., M. Marounek, and K. Holub. 1987. Testing the suitability of the addition of Trichoderma viride cellulases to feed rations for ruminants. Zivocisna Vyroba. 32:587-592.

Kung, L., Jr., R. J. Treacher, G. A. Nauman, A. M. Smagala, K. M. Endres, and M. A. Cohen. 2000. The effect of treating forages with fibrolytic enzymes on its nutritive value and lactation performance of dairy cows. J. Dairy Sci. 83:115-122.

Lewis, G. E., W. K. Sanchez, C. W. Hunt, M. A. Guy, G. T. Pritchard, B. I. Swanson, and R. Treacher. 1999. Effect of direct-fed dibrolytic enzymes on the lactational performance of dairy cows. J. Dairy Sci. 82:611-617.

Morgavi, D. P., K. A. Beauchemin, V. L. Nserko, L. M. Rode, A. D. Iwaasa, W. Z. Yang, T. A. McAllister, and Y. Wang. 2000. Synergy between ruminal fibrolytic enzymes and enzymes from Trichoderma Longibrachiatum. 83:1310-1321.

Nelson, N. 1944. A photometric adaptation of the Somogyi method for the determination of glucose. J. Biol.Chem. 153:376x-379.

Oba, M., and M. S. Allen. 2000. Effects of brown midrib 3 mutation in corn silage on productivity of dairy cows fed two concentrations of dietary neutral detergent fiber: 2 . chewing activities. J. Dairy Sci. 83:1342-1349.

Orskov, E. R., and J. McDonald. 1979. The estimation of protein degradability in the rumen from incubation measurements 
weighted according to rate of passage. J. Agric. Sci. (Camb.) 92:499-503.

Poore, M. H., J. A. Moore, T. P. Eck, R. S. Swingle, and C. B. Theurer. 1993. Effect of fiber source and ruminal starch degradability on site and extent of digestion in dairy cows. J. Dairy Sci. 76:2244-2253.

Robertson, J. B., and P. J. Van Soest. 1981. The detergent system of analysis and its application to human foods. Pages 123-158 in The Analysis of Dietary Fiber in Food. W. P. T. James and O. Theander, eds., Marcel Dekker, Inc., New York.

Rode, L. M., W. Z. Yang, and K. A. Beauchemin. 1999. Fibrolytic enzyme supplements for dairy cows in early lactation. J. Dairy Sci. 82:2121-2126.

Russell, J. B., and D. B. Wilson. 1996. Why are ruminal cellulolytic bacteria unable to digest cellulose at a low pH. J. Dairy Sci. 79:1503-1509.
SAS User's Guide: Statistics, Version 7th Edition. 1998. SAS Inst., Inc., Cary, NC.

Schingoethe, D. J., G. A. Stegman, and R. J. Treacher. 1999. Response of lactating dairy cows to a cellulase and xylanase enzyme mixture applied to forages at the time of feeding. J. Dairy Sci. 82:996-1003.

Stokes, M. R., and S. Zheng. 1995. The use of carbohydrase enzymes as feed additives for early lactation cows. Page 35 in Proc. 23 Biennial Conf. on Rumen Function. Chicago, IL.

Van Soest, P. J., J. B. Robertson, and B. A. Lewis. 1991. Methods for dietary fiber, neutral detergent fiber, and nonstarch polysaccharides in relation to animal nutrition. J. Dairy Sci. 74:3583-3597.

Yang, W. Z., K. A. Beauchemin, and L. M. Rode. 2000. Effects of barley grain processing on extent of digestion and milk production of lactating cows. J. Dairy Sci. 83:554-568. 